\title{
Environmental control of the breeding success of rhinoceros auklets at Triangle Island, British Columbia
}

\author{
Gary Borstad $^{1, *}$, William Crawford ${ }^{2}$, J. Mark Hipfner ${ }^{3}$, Richard Thomson ${ }^{2}$, \\ Kim Hyatt ${ }^{4}$
}

\author{
${ }^{1}$ ASL Environmental Sciences Inc., Victoria, British Columbia, V8M 1Z5, Canada \\ ${ }^{2}$ Institute of Ocean Sciences, Fisheries and Oceans Canada, Sidney, British Columbia, V8L 4B2, Canada \\ ${ }^{3}$ Environment Canada, RR\#1 5421 Robertson Road, Delta, British Columbia, V4K 3N2, Canada \\ ${ }^{4}$ Pacific Biological Station, Fisheries and Oceans Canada, Nanaimo, British Columbia, V8L 4B2, Canada
}

\begin{abstract}
There are few studies of the mechanistic links between physical environmental processes and biotic responses in marine ecosystems that have strong predictive power. At Triangle Island, the largest seabird colony along Canada's Pacific coast, annual breeding success of rhinoceros auklets Cerorhinca monocerata varies dramatically. Previous studies have correlated this variability with ocean temperature, but this relationship occasionally fails, suggesting that it is not causal. We used historical satellite data time series of sea surface temperature, chlorophyll, and winds to study the oceanography of this remote colony. We found that rhinoceros auklets bred more successfully when the spring transition in regional winds and the resulting spring phytoplankton bloom occurred early in April. These factors appear to control the annual recruitment of Pacific sandlance Ammodytes hexapterus, as measured by the percent by biomass of young-of-the-year sandlance in the nestling diet. These linkages imply bottom-up control in this system. Suggesting broader implications of our work, we also found that marine survival of economically and culturally important sockeye salmon Oncorhynchus nerka from nearby Smith Inlet was strongly correlated with the fledgling mass of the rhinoceros auklets, sandlance in the chicks' diets, and regional chlorophyll in April. The timing of the spring wind transition and phytoplankton bloom appear to be important for other predators in this system. We think that these relationships with wind and chlorophyll derived from satellite data are potentially valuable explanatory tools that will be widely applicable to studies of early marine survival of many marine species.
\end{abstract}

KEY WORDS: Rhinoceros auklet · Ocean chlorophyll • Ocean temperature · Wind · Satellite imagery · Sandlance $\cdot$ Salinity $\cdot$ Sockeye salmon $\cdot$ Triangle Island

\section{INTRODUCTION}

There have been profound changes in the manner in which marine ecosystems function in recent decades, related to causes as diverse as ocean warming, acidification, eutrophication, and overfishing (Edwards \& Richardson 2004, Myers \& Worm 2005, Fabry 2008, Richardson 2008). In order to predict the future ecological consequences of these changes, and to aid development of programs to mitigate their effects, a more comprehensive understanding of how marine ecosystems function is needed. This includes the mechanisms that link abiotic, physical environmental processes such as wind and heat transfer to the full spectrum of biotic responses from primary production to top predators (Aebischer et al. 1990, Croll et al. 2005). Detailed comprehensive studies of this nature with strong predictive power remain in short supply (McGowan et al. 1998, Watanuki et al. 2009). This shortcoming probably reflects the size and 4-dimensional complexity of marine ecosystems in general, the resulting cost and therefore paucity of appropriate in situ ship measurements, and also the justifiable tendency to use simple, easy-to-quantify proxies for the intricately related 
suite of abiotic and biotic factors that actually drive ecosystem processes (Wells et al. 2008).

Marine birds are often used as the upper-trophiclevel endpoints in studies of how environmental variation affects marine ecosystem function (Ainley \& Boekelheide 1990). They are well suited to this role because they are relatively easy to study on their breeding colonies compared to consumer taxa that spend all or most of their time underwater (Cairns 1987). A number of studies have demonstrated strong concordance between seabird breeding parameters such as laying date and reproductive success, and population processes in other marine predators, including commercially important fish and crustacean stocks (Miller \& Sydeman 2004, Davoren \& Montevecchi 2003, Reed et al. 2006). This concordance reflects the value of seabirds as 'indicators' of the state of marine food webs, and also signals their potential value to broad-based ecosystem approaches to marine conservation.

Triangle Island, British Columbia, Canada $\left(50^{\circ} 52^{\prime} \mathrm{N}\right.$, $129^{\circ} 05^{\prime} \mathrm{W}$ ) is the outermost island in the Scott Islands archipelago and the site of the numerically largest seabird colony along Canada's Pacific coast (Fig. 1). Seabirds at Triangle Island have been studied periodically since 1975, and in every year since 1994, with observations on the timing and success of breeding in several species.

In the years from 1977 to 2001, there was a strong negative relationship between the growth rates of nestling rhinoceros auklets at Triangle Island and springtime sea surface temperature (SST) measured at the Pine Island light station $100 \mathrm{~km}$ to the east (Bertram et al. 2001). SST is widely used in marine studies as a general proxy for ocean productivity, and is in general a reliable predictor of breeding success at seabird colonies in the California Current System (Abraham \& Sydeman 2004, Thayer et al. 2008), including Triangle Island (Bertram et al. 2001, Gjerdrum et al. 2003, Hipfner 2008a). It is also widely used with considerable success in more broadly based studies of how this and other large marine ecosystems function (e.g. Mackas et al. 2007, Whitehead et al. 2010). However, springtime SST overestimated growth rates in the cold ocean year of 1976 so severely that it drove an otherwise strong relationship to statistical insignificance (Bertram et al. 2001), and SST likewise grossly overestimated auklet breeding success in 2007 (Hipfner 2008b). These relationships between seabird breeding success and SST are usually attributed to impacts on the availability of exothermic prey types (e.g. crustaceans, fish) rather than to direct thermic effects on the birds themselves (Bertram et al. 2001, Hedd et al. 2006). However, the fact that they can overtly break down, even within the normal temperature range, suggests that SST need not be the predominant causal factor affecting the relevant population processes in marine prey-and in fact that it need not even accurately gauge the causal factors that are most important.

This raises the question of what these more important causal factor(s) might be. Through the application of satellite imagery, a number of associated studies have uncovered strong relationships between marine functioning and primary productivity across broad geographic areas (e.g. Ware \& Thomson 2005). Alternately, local foraging hotspots for a suite of marine predators sometimes exist where a highly disproportionate amount of trophic energy exchange is focused in very small areas that feature high primary production (e.g. Scott et al. 2010). Given the extreme interannual variation in the productivity of the marine environment around Triangle Island, and its documented effects on consumers in this system-including the seabirds at Triangle Island (Mackas et al. 2007) - we set out to test the hypotheses that: (1) interannual variation in local marine primary productivity, particularly in spring (as crudely indicated by satellite-derived phytoplankton chlorophyll concentrations) is a critical factor driving interannual variation in the breeding success of the rhinoceros auklet, a generalist forager in this system (Davies et al. 2009); (2) that the effect would be due at least in part to its effects on the recruitment of a critical prey species, Pacific sandlance Ammodytes hexapterus, and thus on its availability to the auklets, as suggested previously by Bertram et al. (1991) and Hedd et al. (2006); and (3) that relationships between satellite-derived chlorophyll concentration and seabird success would be applicable to other consumers in the system. To test hypothesis 3, we compared the annual marine survival of nearby cohorts of sockeye salmon Oncorhynchus nerka, the most economically and culturally important fish species in these waters, with several metrics of the annual breeding success of rhinoceros auklets at Triangle Island.

Our primary goal here is to use the marine system around the seabird colony at Triangle Island as a 'model' system for ecosystem trophic functioningspanning the full range from physical environment variables (more specifically, wind speed and direction, temperature, salinity, and photosynthetically active radiation [PAR]) to important primary and then secondary consumers. Since our secondary goal is to show how satellite imagery can be used as the basis for ecosystem studies and eventually for management, we first present the findings from the satellite data, then interpret them, rather than discussing the findings in 'process' order, which might be more logical. We believe that the Triangle Island system is well suited to our purposes because: (1) the system exhibits extreme interannual variation in important abiotic and biotic parameters; (2) we rely heavily on satellite-derived wind, temperature, 


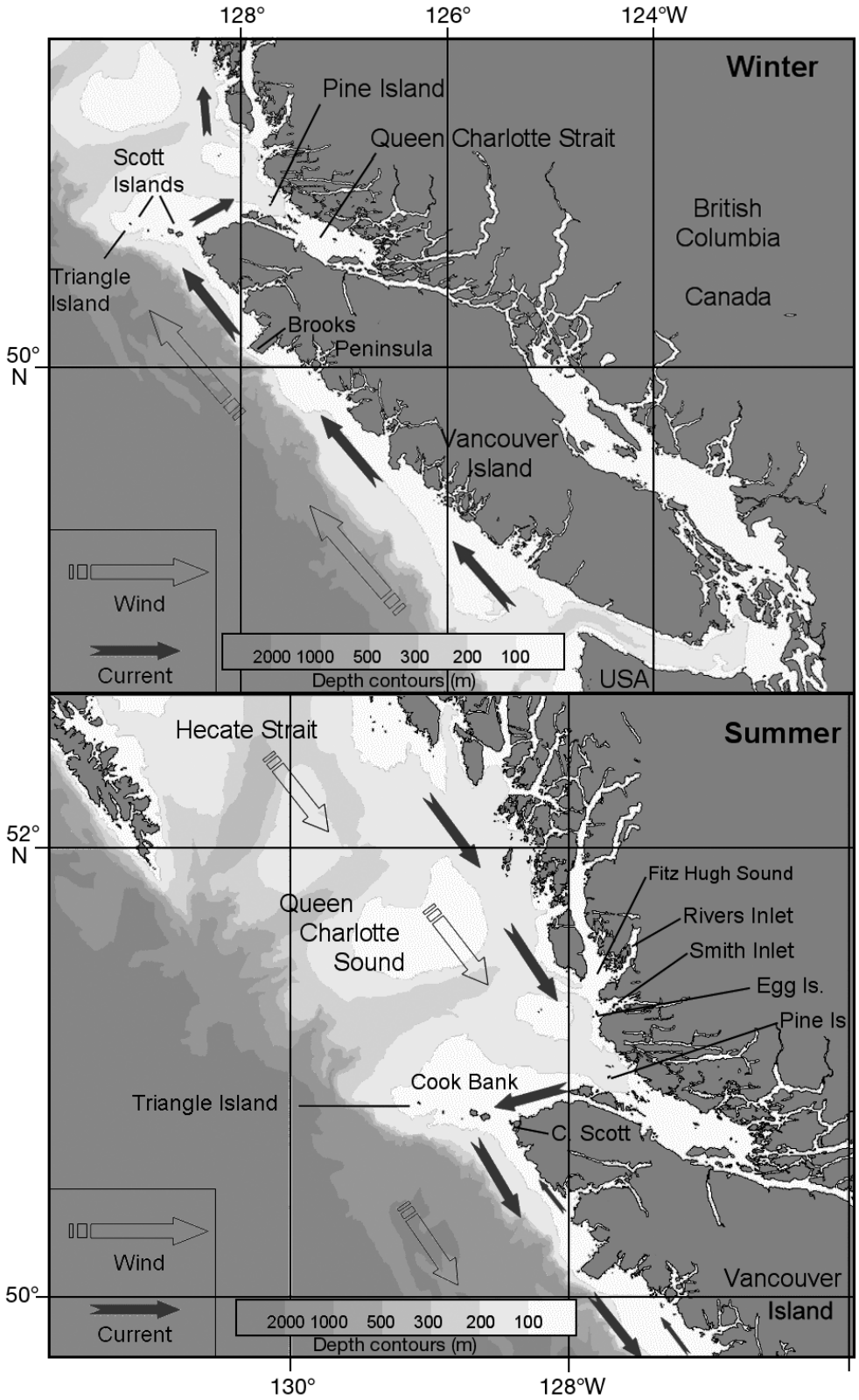

Fig. 1. Study area showing the location of the remote breeding colony of rhinoceros auklets Cerorhinca monocerata at Triangle Island. Triangle Island is the outermost of the Scott Islands Group, lying some $45 \mathrm{~km}$ off the northwest tip of Vancouver Island on the outer edge of Cook Bank. Winds and currents off Vancouver Island are generally from the southeast in the winter and from the northwest in the summer. Ocean shading denotes water depths as indicated on the scale bar. Locations of the places named in the text are marked

and chlorophyll observations that are available globally and therefore applicable to marine systems everywhere; (3) the multi-year global satellite dataset is now sufficiently long that it captures the full range of annual environmental conditions at our study site-including transitions to and from marine conditions described by Mackas et al. (2007) as 'warm, low productivity' (e.g. an extreme El Niño event in 1998), 'cold, high productiv- ity' (e.g. a strong La Niña in 1999), and an anomalous atmospheric blocking event in 2005 (Sydeman et al. 2006, Mackas et al. 2007); and (4) as outlined below, because we have a solid understanding of the relevant physical environmental mechanisms.

\section{Study area}

Waters surrounding the Scott Islands are generally considered to be in a transition zone between California and Alaska Currents. The summer and winter flow patterns are summarized in Fig. 1. Winds from the southeast during severe storms of autumn and winter push surface currents eastward through these islands towards the coast (Freeland et al. 1984, Crawford et al. 2006). These southeast winter winds relax in the spring, and are replaced by weaker and more frequent winds from the northwest in summer. Coriolis force directs currents to the right of the winds, resulting in summer upwelling along the eastern shore of Queen Charlotte Sound and along the west coast of Vancouver Island, and a flow towards the west across Cook Bank and through the Scott Islands (Crawford et al. 1985). The cool temperatures of this westward flow arise from upwelling and tidal mixing of cold waters off Smith Inlet, outflow of well mixed waters from Queen Charlotte Strait, and from tidal mixing over Cook Bank and especially around the Scott Islands, where tidal currents can reach a peak speed of 3.5 knots. Rivers flowing into Rivers Inlet and Smith Inlet are the most significant source of fresh water between the Skeena and Fraser Rivers, located hundreds of $\mathrm{km}$ to the north and south, respectively, of our study area.

\section{Study species}

The rhinoceros auklet is a highly colonial, burrow-nesting seabird with an adult weight of approximately $500 \mathrm{~g}$. The birds begin arriving at Triangle Island in the first half of April. Egg-laying begins in the last week of April or the first week of May, with median laying dates in recent years in the first half of May (Hipfner et al. 2008). Eggs are incubated for about $45 \mathrm{~d}$ before they hatch (most in mid to late June), and offspring are fed in the nest by both parents for about $54 \mathrm{~d}$ on average before they leave the nest to begin an independent life at sea in mid-August (Bertram et al. 2001). 
Although the diet of adult rhinoceros auklets includes large crustaceans, squid and fish (Davies et al. 2009, Ito et al. 2009), chicks are fed mainly a range of small forage fish (Thayer et al. 2008) derived mostly from the top $10 \mathrm{~m}$ of the water column (Burger et al. 1993). At Triangle Island, breeding success is maximal in years in which the population as a whole lays early (Hipfner et al. 2008) and nestling diets are rich in juvenile sandlance Ammodytes hexapterus (Bertram et al. 1991, Hedd et al. 2006).

\section{MATERIALS AND METHODS}

Rhinoceros auklet fledgling production calculations. Details of the methods used to monitor timing and success of rhinoceros auklet breeding at Triangle Island, as well as nestling diets for the period between late (28-30 in all years) June and early August (9-12 in all years), are described elsewhere (Hipfner et al. 2008). We separately examined correlations between ocean conditions and annual: (1) hatching success (\% of eggs laid that survive to hatching); (2) fledging success $(\%$ of hatched chicks that survive until they leave the nest, at which time they are independent of their parents); and (3) fledgling mass (the mass of the nestling when it leaves the nest). Each of these metrics provides a measure of success of the birds at a different stage of the breeding season. As a single measure of annual breeding success, we used (4) the average mass (g) of fledged chick produced per egg laid (denoted fledgling production) calculated as the product of the 3 individual metrics noted above (Hipfner et al. 2008). (Unless specifically mentioned, all correlations described are linear.)

Satellite-derived data. AVHRR (Advanced Very High Resolution Radiometer) Pathfinder image data of global monthly daytime sea surface temperature (SST) for the years 1985 to 2006 were downloaded from the NASA Jet Propulsion Laboratory Physical Oceanography Distributed Active Archive Center (PO.DAAC) website (ftp: //podaac.jpl.nasa.gov/pub/sea_surface_temperature/ avhrr/pathfinder/data_v5/monthly/day $/ 04 \mathrm{~km} /$ ). This dataset (product 216) gives monthly mean daytime temperature at $4 \mathrm{~km}$ spatial resolution. For the years 2007 and 2008, we obtained MODIS sea surface temperature products from the NASA Ocean Color website (ftp://oceans. gsfc.nasa.gov/MODISA/Mapped/Monthly/4/SST4/).

Similarly, data from the SeaWiFS satellite sensor describing the distribution of chlorophyll $a$ in the ocean (level 3 global monthly and $9 \mathrm{~km}, 8 \mathrm{~d}$ chlorophyll version 4, OC4 algorithm) for 1998 to 2008 were downloaded from the NASA Goddard Space Flight Center (GSFC) Ocean Color website (ftp://oceans.gsfc.nasa. gov/SeaWiFS/Mapped/). PAR was examined through
SeaWiFS observations, using values of PAR prepared and archived on-line by NASA. PAR is defined as the quantum energy flux from the sun in the spectral range of 400 to $700 \mathrm{~nm}$, which is the band of radiation that stimulates photosynthesis.

Near-surface wind fields were derived from the SeaWinds Ku band microwave scatterometer on the QuikBird satellite (usually referred to as QuikSCAT to distinguish it from a similar instrument on ADEOS-2). QuikSCAT is a radar that transmits microwave pulses toward the sea surface and measures the power reflected back to the sensor. The backscattered power is a function of surface roughness due to $\mathrm{cm}$ scale capillary waves, which are both related to near-surface wind speed and direction. Average QuikSCAT wind speed and direction were reported twice a day with $15 \mathrm{~km}$ grid spacing over the ocean from June 1999 until November 2009. We used QuikSCAT winds produced by Remote Sensing Systems Inc. and sponsored by NASA ocean vector winds science team (www. remss.com).

The AVHRR, MODIS, and SeaWiFs satellite data were originally acquired at daily intervals and $1 \mathrm{~km}$ spatial resolution and the valid data binned by NASA into the lower resolution $8 \mathrm{~d}$ and monthly composites that we downloaded (Fig. 2). For our purposes, such compositing very effectively reduced data losses due to clouds. We further reduced these data losses by computing spatial averages over the 3 circles in Fig. 2 to produce the chlorophyll time series in Fig. 3. For QuikSCAT we calculated area-averaged winds for a $65 \times 65 \mathrm{~km}$ area of southeast Queen Charlotte Sound between $51.5^{\circ} \mathrm{N}, 129^{\circ} \mathrm{W}$ and $51^{\circ} \mathrm{N}, 128.2^{\circ} \mathrm{W}$. We used this time series of wind speed and direction to calculate daily along-shore winds. We then filtered these to produce a $5 \mathrm{~d}$ running average for the period 1999 to 2008.

Because the average foraging range of rhinoceros auklets is 80 to $90 \mathrm{~km}$ (Kato et al. 2003, McFarlaneTranquilla et al. 2005), and because Bertram et al. (2001) found links between auklet nestling growth rates and April SST, we initially searched for correlations of annual fledgling production versus average April chlorophyll concentration as determined by satellite, within a $90 \mathrm{~km}$ radius (region of interest, ROI) near Triangle Island and the northwest tip of Vancouver Island (outer red circle in Fig. 2) and 2 other smaller zones of radii 45 and $15 \mathrm{~km}$. The zones do not appear circular because of the map projection used.

Due to the rather crude temporal resolution of the chlorophyll monthly averages, we also more closely examined the timing of events using the $8 \mathrm{~d}$ composite chlorophyll imagery. We extracted spatial averages from each $8 \mathrm{~d}$ composite within the $15 \mathrm{~km}$ radius zone since it produced a time series most closely representing events near the island (Fig. 3). We then calculated 

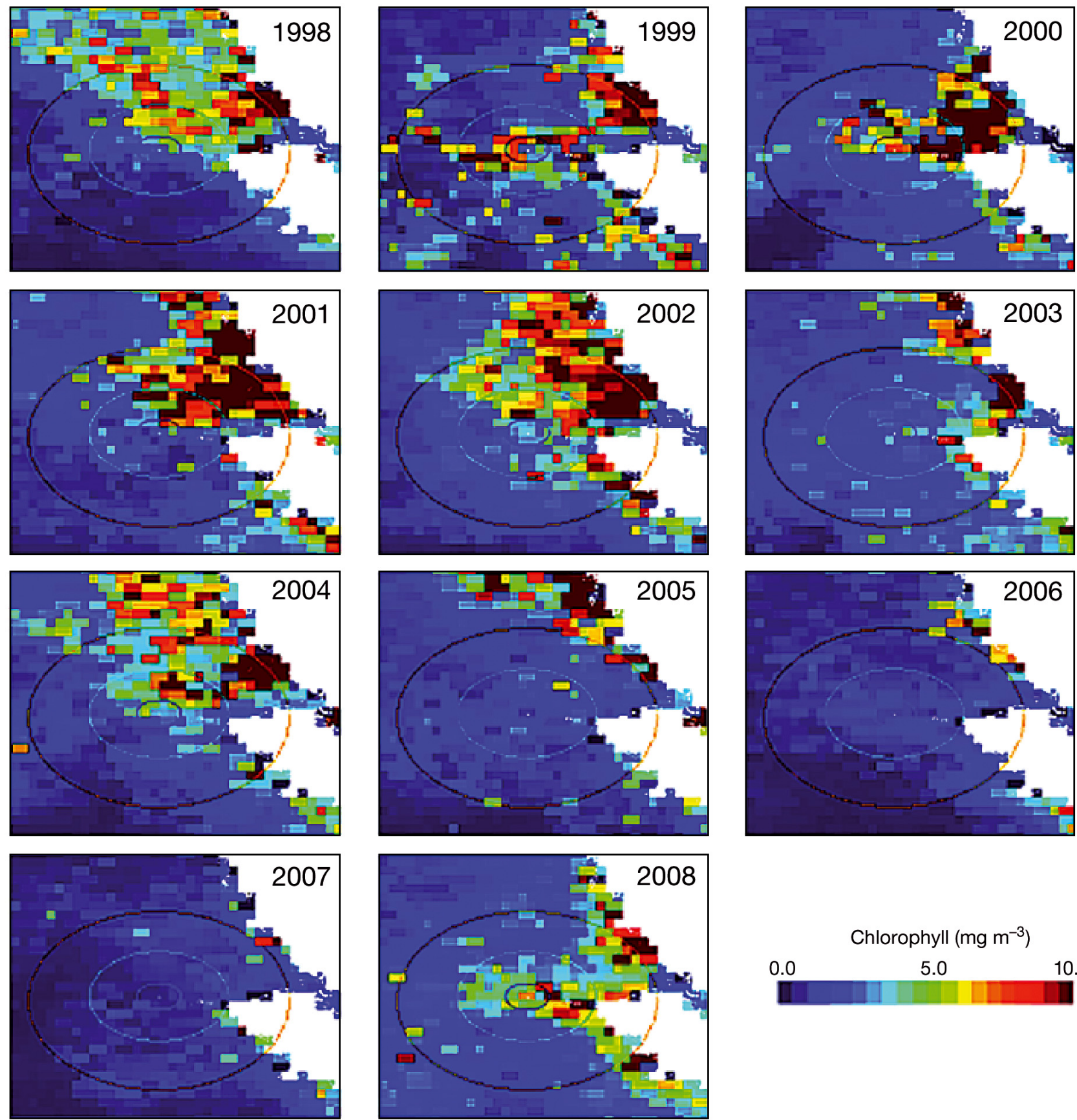

Chlorophyll $\left(\mathrm{mg} \mathrm{m}^{-3}\right)$

0.0

5.0

10.0

Fig. 2. Composite chlorophyll time series derived from the SeaWiFS satellite sensor for southeastern Queen Charlotte Sound for the month of April from 1998 to 2008, shown with 90, 45, and $15 \mathrm{~km}$ radius circles centered on Triangle Island. Circles appear as ellipses because of the map projection used

several indices of the phenology of the phytoplankton including the timing of the initial increase in chlorophyll concentration around the island in spring, calculated as the date on which average chlorophyll first increased above $2 \mathrm{mg} \mathrm{m}^{-3}$ (a value significantly higher than normal winter concentrations, i.e. $<1 \mathrm{mg} \mathrm{m}^{-3}$, but well below peak bloom concentrations, which in this area are between 6 and $15 \mathrm{mg} \mathrm{m}^{-3}$ ).
All local image processing was done using the commercial image processing software ENVI ${ }^{\mathrm{TM}}$ (ITT Visual Information Solutions).

In situ measurements. Mean monthly SST and salinity calculated from daily measurements at the Pine Island and Egg Island light stations (Fig. 1) located $\sim 100 \mathrm{~km}$ east (at $50.58^{\circ} \mathrm{N}, 127.44^{\circ} \mathrm{W}$ and $51.2^{\circ} \mathrm{N}$ $127.8^{\circ} \mathrm{W}$, respectively) were obtained from the Depart- 


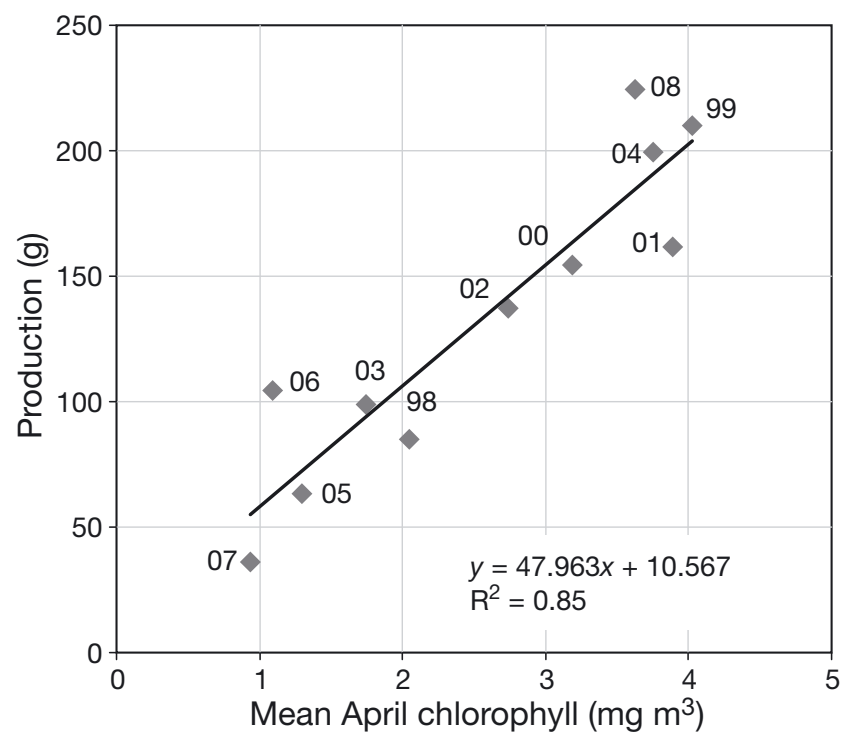

Fig. 3. Cerorhinca monocerata. Relationship between fledgling production and average April chlorophyll concentration within the $45 \mathrm{~km}$ zone for the years 1998-2008

ment of Fisheries and Oceans website at www.pac.dfompo.gc.ca/science/oceans/data-donnees/lighthousesphares/index-eng.htm.

Sockeye salmon survival. To test whether rhinoceros auklet fledgling production could provide an index of marine productivity relevant to other consumers in the system, we compared the calculated marine survival of economically and culturally important Long Lake sockeye salmon to the metrics of rhinoceros auklet fledgling production. Long Lake sockeye enter the ocean through Smith Inlet (Hyatt et al. 2008) about $100 \mathrm{~km}$ east of Triangle Island (Fig. 1) and, for convenience, will be henceforth referred to as Smith Inlet sockeye. Descriptions of standard methods for estimating annual abundance of juvenile sockeye salmon just prior to their annual seaward migrations from Long Lake and of adult returns derived from each cohort of juvenile sockeye are virtually identical to those described by Hyatt et al. (1984) and McKinnell et al. (2001).

\section{RESULTS}

\section{Satellite-derived chlorophyll and correlations with auklet breeding success}

\section{General pattern of April chlorophyll}

Examination of the $8 \mathrm{~d}$ composite chlorophyll images (data not shown) revealed that spring chlorophyll blooms began on the mainland coast near the mouth of Fitz Hugh Sound in late March and early April and extended south and westward during April, when there was wind from the north. Wind from the south pushed these high chlorophyll waters to the north and east away from Triangle Island. There are 2 patterns of April chlorophyll distribution in southeast Queen Charlotte Sound illustrated in Fig. 2. In some years (1998, 2001, 2002, and 2004), pigment concentrations were elevated across the entire southeast portion of the sound to the north and east of Triangle Island. In other years $(2003,2005,2006$, and 2007), there was very little chlorophyll in this area in April. In some years, the high chlorophyll water mass appeared in a narrower band extending from Fitz Hugh Sound on the mainland coast directly to Triangle Island. In many chlorophyll images for individual days, and even in some of the monthly average images for April in Fig. 2 (especially in 1999, 2000), this 'plume' of high chlorophyll water can be seen extending to the vicinity of Triangle Island from the Smith and Rivers Inlet area.

\section{Seasonal relationships}

Comparing of regional chlorophyll derived from satellite imagery with breeding metrics, we found strongest correlations for the $45 \mathrm{~km}$ zone. Correlations were lower in both the 90 and $15 \mathrm{~km}$ zones. We found extremely strong relationships in comparing fledging success, fledging mass, and fledgling production with monthly average chlorophyll within the $45 \mathrm{~km}$ zone in April (Table 1, Fig. 2), coinciding with the spring bloom in these waters. There were much weaker relationships with other months.

Timing of the arrival of the high chlorophyll water mass at the colony

The spring bloom in southern Queen Charlotte Sound develops across a wide area east of Triangle Island and over a period of 1 or $2 \mathrm{wk}$. We can see westward extension of chlorophyll plumes in the spring during conditions of winds from the north, which are known to cause a westward current over Cook Bank. We therefore think that the increase of chlorophyll seen at Triangle Island does not represent a local bloom, but mostly transport of high chlorophyll from further east. The timing of the first arrival of water masses with elevated chlorophyll $>2 \mathrm{mg} \mathrm{m}^{-3}$ at the colony varied considerably from year to year (Fig. 4). In the 1998 El Niño year, there was a short-lived passage of high chlorophyll waters past the colony in midMarch, but between 1999 and 2008 the first significant elevated concentrations began in April. In the years 1999 to 2001, high chlorophyll concentrations arrived 
Table 1. Cerorhinca monocerata. Coefficient of determination (linear fit) of monthly chlorophyll in the $45 \mathrm{~km}$ zone with rhinoceros auklet production metrics are highest in April. A second order equation explains the fit with fledging success extremely well (for April only, $\mathrm{R}^{2}$ for these 2 nd order equations are shown in brackets). Bold indicates correlations significant at or above the 0.01 level for the $\mathrm{n}$ indicated. Negative signs indicate squared correlations with negative slopes

\begin{tabular}{|lrccc|}
\hline Breeding parameter & March & April & May & June \\
\hline Hatching success $(H)$ & 0.00 & $0.47(\mathbf{0 . 5 7})$ & 0.04 & 0.22 \\
Fledging success $(F)$ & 0.01 & $\mathbf{0 . 7 6}(\mathbf{0 . 9 1 )}$ & 0.00 & 0.18 \\
Fledgling mass $(M)$ & -0.11 & $\mathbf{0 . 7 1}(\mathbf{0 . 7 1})$ & 0.02 & 0.23 \\
Fledgling production & -0.01 & $\mathbf{0 . 8 5}(\mathbf{0 . 8 5})$ & 0.02 & 0.30 \\
$(P=H \times F \times M)$ & 10 & 11 & 11 & 11 \\
$\mathrm{n}(\mathrm{yr})$ & 0.4 & 0.36 & 0.36 & 0.36 \\
$\mathrm{p}=0.05$ & 0.59 & 0.54 & 0.54 & 0.54 \\
$\mathrm{p}=0.01$ & & & & \\
\hline
\end{tabular}

early in April, but between 2004 and 2007 the local chlorophyll peak concentration became progressively later. It was fully 1 mo late in 2007 , but reverted to early April in 2008.

Based on Fig. 5, it is the precise timing of the first arrival of high chlorophyll waters around the colony that is critical to the success of rhinoceros auklets. Linear correlations are very low because of the early increase in concentrations in 1998, but a second order fit describes the relationship between percentage of chicks that fledged and chlorophyll timing extremely well $\left(R^{2}=0.96, n=11, p<0.0001\right.$; where $n$ is the sample size and $\mathrm{p}$ is the probability of obtaining an $\mathrm{R}^{2}$ of this magnitude by chance) for the period 1998 to 2008 . The highest fledging success occurred in years when the chlorophyll observed around the island first began to increase in early April. In 1998, the high chlorophyll waters that arrived on March 23 were apparently too early, or too weak and too short in duration. Second order fits to hatching success, fledgling mass, and fledgling production have $\mathrm{R}^{2}=0.40,0.77$, and 0.78, respectively, which are also higher than for the average monthly chlorophyll concentration, but more or less in the same relative order of importance. The timing of the arrival of high chlorophyll waters during April explains why the average chlorophyll for the calendar month of April captures the relationship well. In 1999, the high chlorophyll water arrived later than in 2000, 2001, and 2008, but achieved higher peak concentration and thus the April chlorophyll concentration was higher (Fig. 2).

Relationship between chlorophyll concentration and the diet fed to the chicks

Fledgling production varied in close relationship with the amount of Pacific sandlance fed to the chicks, which declined progressively between 1999 and 2007 (Fig. 6). Our chlorophyll data clearly show that when the spring bloom was earlier, the chicks received a diet richer in sandlance during July and August $\left(\mathrm{R}^{2}=0.79, \mathrm{n}=11, \mathrm{p}<\right.$ 0.001; Fig. 7). As with fledging success, the 1998 chlorophyll increase appears to have been too early or too brief to have caused an increase in the amount of sandlance in the nestling diets. There was a very strong positive relationship between the \% biomass of sandlance in the diet and fledging success $\left(\mathrm{R}^{2}=0.84, \mathrm{n}=11, \mathrm{p}<0.001\right)$ with a second order curve that reached an asymptote around 35\% sandlance in diets and 95\% fledging success (Fig. 8). Correlations $\left(\mathrm{R}^{2}\right.$ in second order fits) with hatching success, fledgling mass, and fledgling production were lower $(0.25,0.67$, and 0.63$)$.

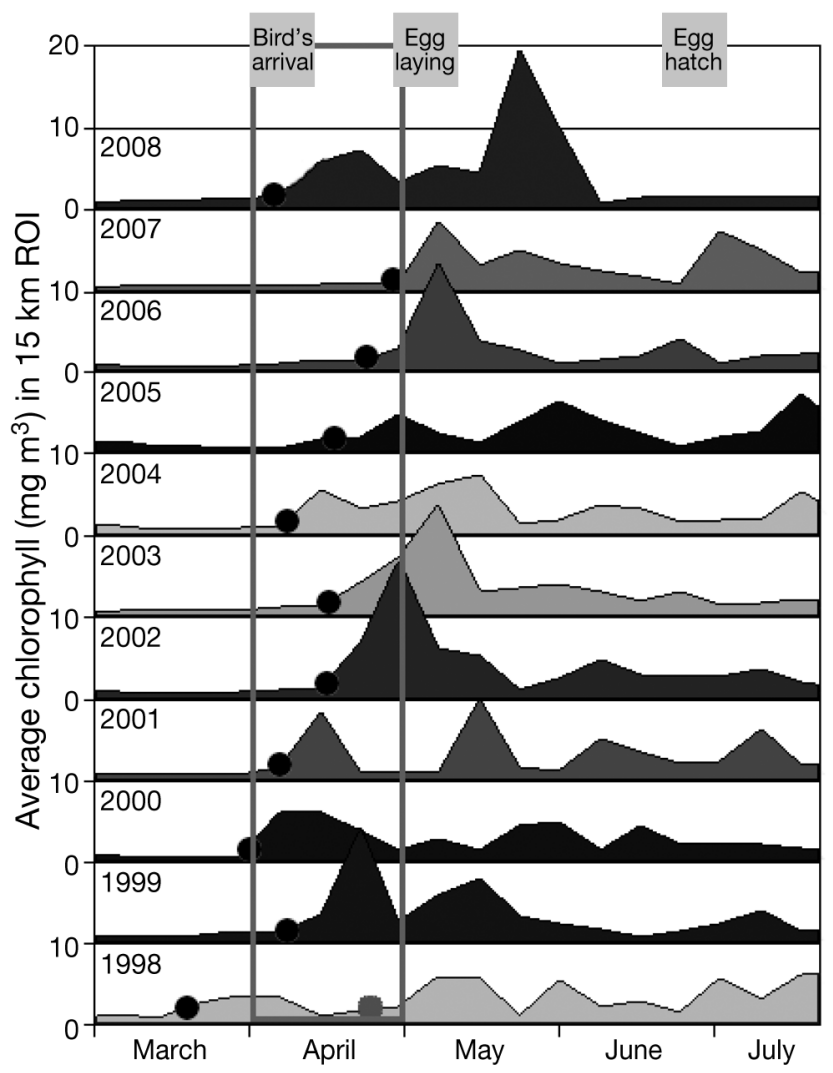

Fig. 4. Time series of surface chlorophyll $\left(\mathrm{mg} \mathrm{m}^{-3}\right)$ averaged within the $15 \mathrm{~km}$ region of interest (ROI) at $8 \mathrm{~d}$ intervals show considerable interannual variation throughout the spring and early summers of 1998 to 2008. All are plotted on the same vertical scale, but are 'stacked' with constant offsets to allow comparison. : beginning of the first increase in chlorophyll concentrations at the island, as measured by the date on which concentrations first rose above $2 \mathrm{mg} \mathrm{m}^{-3}$. second increase in 1998. Grey box emphasizes the month of April 


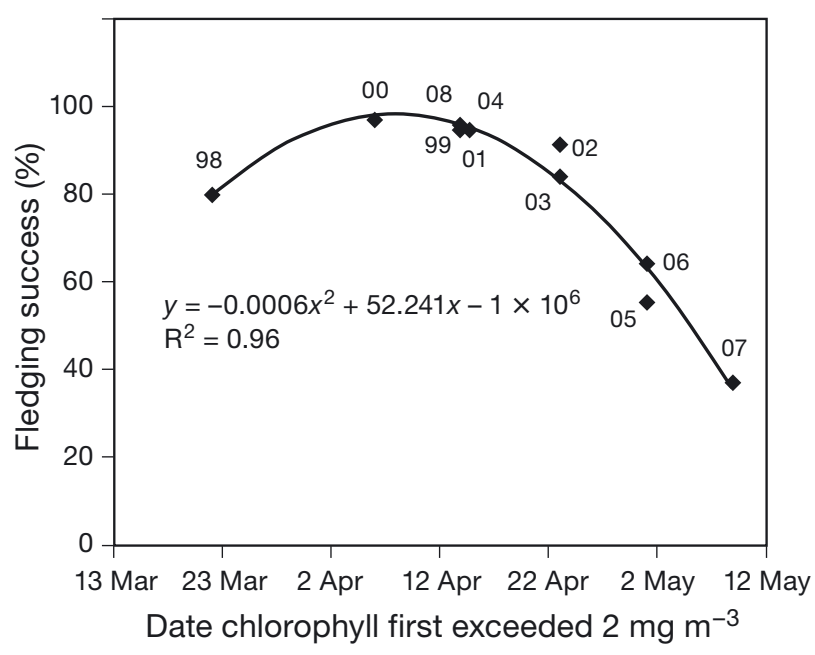

Fig. 5. Cerorhinca monocerata. Relationship between fledging success and timing of the spring bloom (chlorophyll $>2 \mathrm{mg} \mathrm{m}^{-3}$ ) suggests that the first $2 \mathrm{wk}$ of April are critical. The early bloom in the 1998 El Niño year appears to have been too early. From 2002 to 2007 the bloom became progressively later until it was a full month late in 2007. Numbers next to data points are years (yy)

Between 1998 and 2008, there was a strong positive linear relationship between the average April chlorophyll concentration the percentage of juvenile young of the year sandlance in nestling diets from late June to early August $\left(R^{2}=0.61, n=10, p=0.005\right.$; not plotted), and an even stronger relationship with the sum of adult and juveniles $\left(R^{2}=0.77, n=10, p=0.0004\right)$. For adult sandlance alone, the percentage in the diet was not related to April chlorophyll in the current year $\left(\mathrm{R}^{2}=\right.$ 0.08), but was related to chlorophyll concentration in the previous year (2nd order fit $\mathrm{R}^{2}=0.49, \mathrm{n}=11$, $\mathrm{p}=0.017$ ), when many of these adult sandlance were year 0 juveniles.

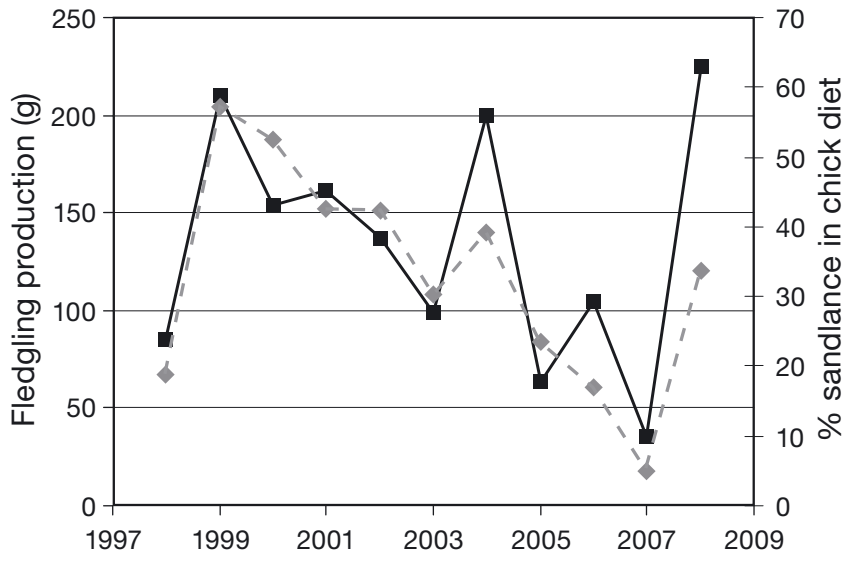

Fig. 6. Cerorhinca monocerata. Proportion of the chick diet contributed by sandlance Ammodytes hexapterus ( $\diamond$ ) declined from 1999 to 2007, and then reversed, in concert with fledgling production (匹)

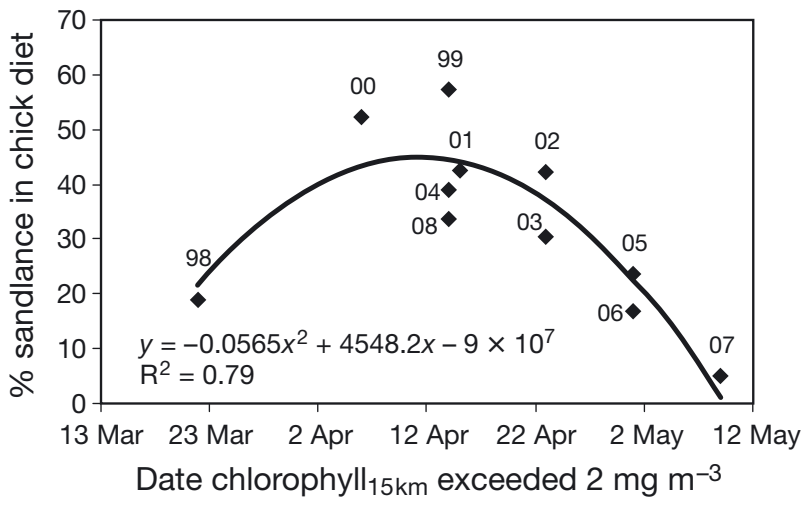

Fig. 7. Cerorhinca monocerata. Relationship between chick diet and the timing of elevated chlorophyll within the $15 \mathrm{~km}$ region of interest. When the bloom arrived during early April, the chicks received a diet rich in sandlance Ammodytes hexapterus. The chicks received relatively little sandlance following the early bloom of 1998, and progressively less as the bloom became later between 2001 and 2007. Numbers next to data points are years (yy)

\section{Relationships with other physical variables}

Sea surface temperature

Table 2 summarizes a comparison of rhinoceros auklet breeding success and SST measured by satellite within the $15 \mathrm{~km}$ radius of the colony at Triangle Island for all months between March and August from 1998 to 2008. Comparisons with SST from Pine Island were very similar (data not shown). We found stronger negative correlations as the summer progressed with SST, whether measured by satellite or measured at Pine Island.

Because the individual $8 \mathrm{~d}$ composite chlorophyll images suggested movement of water from the vicinity of Smith Inlet towards Triangle Island in agreement

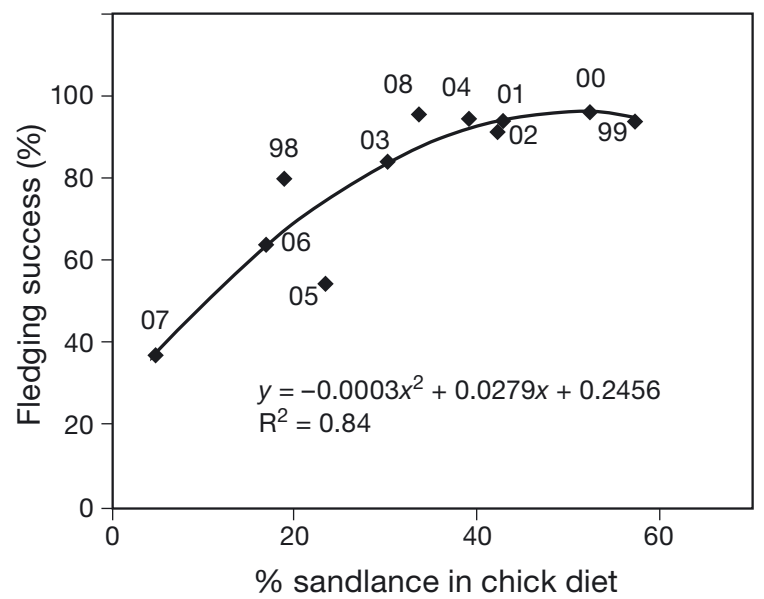

Fig. 8. Cerorhinca monocerata. Fledging success increased with the proportion of sandlance Ammodytes huxapterus in the chick diet, up to about $30 \%$ sandlance. Numbers next to data points are years (yy) 
Table 2. Cerorhinca monocerata. Coefficient of determination between sea surface temperature (SST) measured by satellite within $15 \mathrm{~km}$ radius of the colony and metrics of rhinoceros auklet chick production at Triangle Island for the period 1998 to 2008 are strongest on fledgling mass, increasing from March until July and decreasing in August. Negative $\mathrm{R}^{2}$ indicates squared correlations with negative slopes. Correlations with hatching success for months following hatching were not calculated

\begin{tabular}{|c|c|c|c|c|c|c|}
\hline Breeding parameter & March & April & May & June & July & August \\
\hline Hatching success $(H)$ & -0.14 & -0.13 & -0.08 & -0.34 & & \\
\hline Fledging success $(F)$ & -0.01 & -0.14 & -0.13 & -0.36 & -0.41 & -0.12 \\
\hline Fledgling mass $(M)$ & -0.27 & -0.50 & -0.50 & -0.65 & -0.73 & -0.40 \\
\hline Fledgling production $(P=H \times F \times M)$ & -0.15 & -0.31 & -0.25 & -0.63 & -0.46 & -0.54 \\
\hline $\mathrm{n}(\mathrm{yr})$ & 10 & 11 & 11 & 11 & 10 & 11 \\
\hline $\mathrm{p}=0.05$ & 0.4 & 0.36 & 0.36 & 0.36 & 0.36 & 0.36 \\
\hline $\mathrm{p}=0.01$ & 0.59 & 0.54 & 0.54 & 0.54 & 0.54 & 0.54 \\
\hline
\end{tabular}

Table 3. Cerorhinca monocerata. Coefficient of determination between sea surface temperature (SST) measured at the Egg Island light station and metrics of rhinoceros auklet chick production for the period 1998 to 2008 are also negative and strongest on fledgling mass in late summer. There are significant correlations with salinity at Egg Island in most months. Correlations with salinity are positive and strongest with fledging success. Negative $\mathrm{R}^{2}$ indicates a negative correlation. Correlations with hatching success for months following hatching were not calculated

\begin{tabular}{|c|c|c|c|c|c|c|}
\hline \multirow{2}{*}{ Breeding parameter } & \multirow{2}{*}{ March } & \multirow[b]{2}{*}{ April } & \multirow[b]{2}{*}{ May } & \multirow[b]{2}{*}{ June } & \multirow[b]{2}{*}{ July } & \multirow[b]{2}{*}{ August } \\
\hline & & & & & & \\
\hline Hatching success $(H)$ & -0.23 & -0.19 & -0.18 & -0.14 & & \\
\hline Fledging success $(F)$ & -0.01 & 0.00 & -0.39 & -0.69 & -0.35 & -0.64 \\
\hline Fledgling mass $(M)$ & -0.26 & -0.19 & -0.55 & -0.77 & -0.68 & -0.85 \\
\hline Fledgling production $(P=H \times F \times M)$ & -0.17 & -0.12 & -0.37 & -0.50 & -0.38 & -0.77 \\
\hline \multirow[t]{2}{*}{ Correlation squared $\left(\mathrm{R}^{2}\right)$} & \multicolumn{6}{|c|}{-Salinity- } \\
\hline & March & April & May & June & July & August \\
\hline Hatching success $(H)$ & 0.00 & 0.00 & -0.34 & 0.03 & & \\
\hline Fledging success $(F)$ & 0.62 & 0.57 & 0.18 & 0.56 & 0.33 & 0.61 \\
\hline Fledgling mass $(M)$ & 0.22 & 0.19 & 0.00 & 0.11 & 0.02 & 0.17 \\
\hline Fledgling production $(P=H \times F \times M)$ & 0.16 & 0.14 & -0.03 & 0.15 & 0.02 & 0.18 \\
\hline $\mathrm{n}(\mathrm{yr})$ & 10 & 10 & 9 & 11 & 11 & 10 \\
\hline $\mathrm{p}=0.05$ & 0.40 & 0.40 & 0.44 & 0.36 & 0.36 & 0.40 \\
\hline $\mathrm{p}=0.01$ & 0.59 & 0.59 & 0.64 & 0.54 & 0.54 & 0.59 \\
\hline
\end{tabular}

with known wind driven currents in the area, we also examined correlations with SST at Egg Island (Fig. 1, Table 3). For both Egg and Pine islands, the correlation with fledgling mass was strongest in June, July, and August. Correlations with SST at Egg Island were negative and strongest with fledgling mass, and likewise strengthened after May, peaking in August at $\mathrm{R}^{2}=0.85$ ( $\mathrm{n}=10, \mathrm{p}<0.001)$.

\section{Salinity}

In the period 2000 to 2008, sea-surface salinity at Pine Island in most months was between 31 and 32 parts per thousand (ppt). At Egg Island surface salinity varied through a much greater range, and was generally lowest between May and September, consistent with greater impact of freshwater runoff at this location. In 1976 and 2007 , the 2 years in which the Pine Island SST correlation with auklet breeding success failed, June salinities were fully 5 ppt lower than the neighboring years.
We found no statistically significant correlations between any of the bird metrics and surface salinity at Pine Island. However, there were significant $(p<0.05)$ positive correlations between Egg Island salinity and fledging success for all months between January and April, as well as June and August (Table 3). There was a significant decline in salinity in all months at Egg Island after 2004, and these correlations are largely driven by the years 2005, 2006, and 2007. A greater proportion of chicks fledged in the years when salinities at Egg Island were high.

\section{Winds}

Fig. 9 presents time series of the alongshore component of wind (positive from the northwest, negative from the southeast) for years categorized as 'good' and 'poor' for fledgling production (above and below the average for the 2000 to 2008 period). Compared to the good years, there were significantly more winds from the 


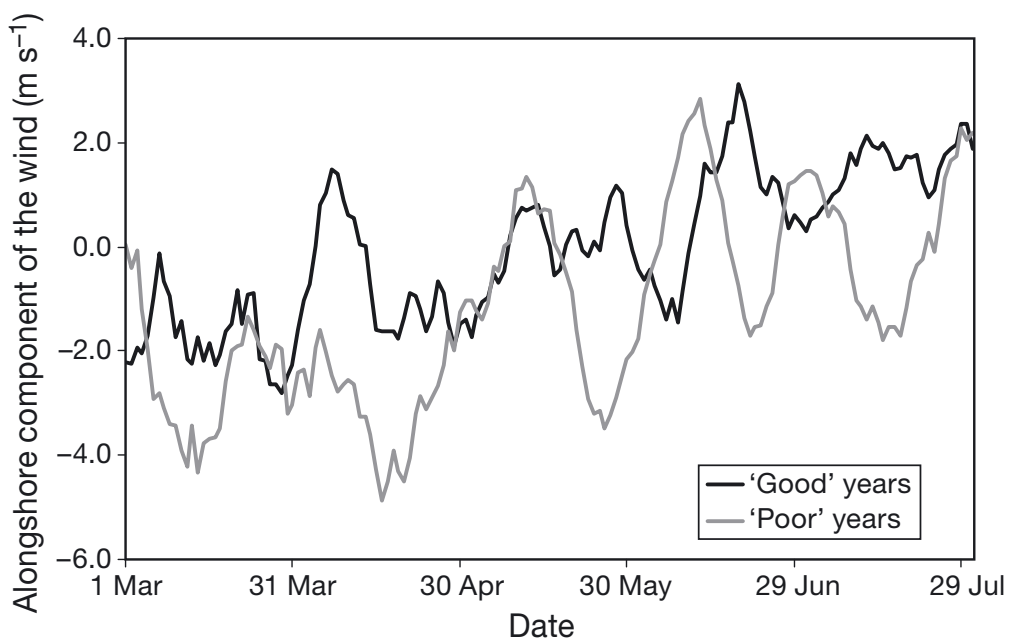

Fig. 9. Time series of alongshore components of the wind averaged for 'good' and 'poor' years of rhinoceros auklet fledgling production during the years 2000-2008, i.e. years above and below average fledgling production, respectively. There were more alongshore winds from the south (negative sign) in southeast Queen Charlotte Sound in 'poor' years especially during the period between 8 and 21 April

south during the poor years through the spring and summer. On average, winds through the winter and spring are from the southeast for both classes of fledgling production, but the difference in winds in early April clearly stands out. Hatching success was not strongly linked to April wind, but the squared correlations of alongshore
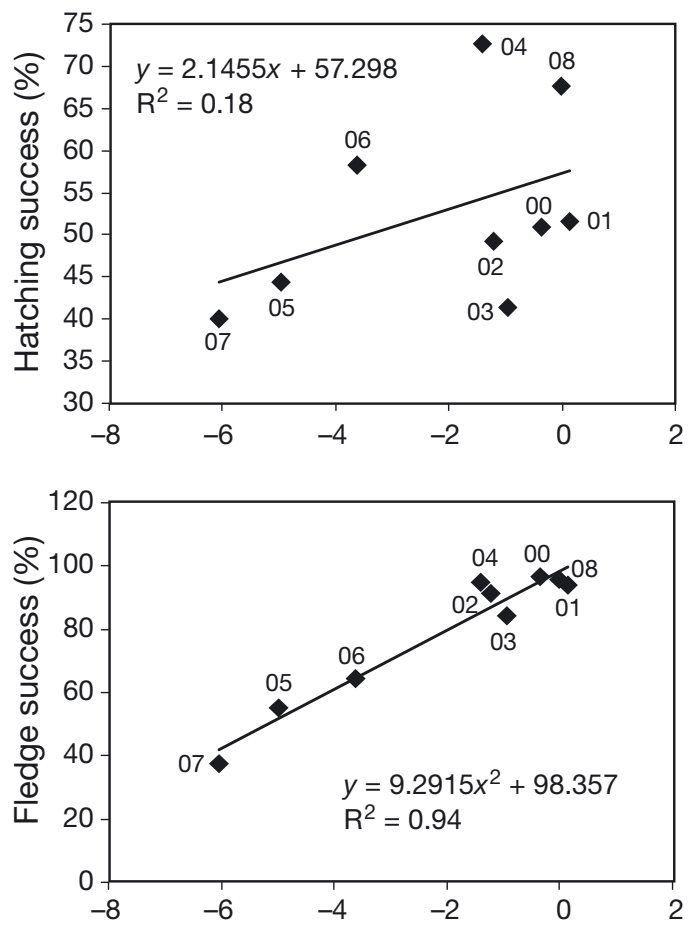

winds with fledging success $\left(R^{2}=0.94, n=9, p \ll\right.$ $0.001)$ and fledgling mass $\left(R^{2}=0.84, n=9, p \ll\right.$ 0.001) were extremely high (Fig. 10). Fledgling production was better in years of significantly weaker southeast winds during the first $3 \mathrm{wk}$ of April, reinforcing the choice of this month as most critical for successful breeding by the auklets on Triangle Island.

\section{Correlation between fledging metrics and salmon marine survival}

For the first $10 \mathrm{yr}$ of the short overlapping time series (1995 to 2004), we found highly significant correlations between $\log _{10}$ Smith Inlet sockeye salmon marine survival and fledgling mass, fledgling production, the proportion of biomass in nestling diets composed of sandlance, and to a lesser extent, fledging success. However, after 2004 all correlations decreased (Table 4) principally due to the occurrence of much higher survival rates for sockeye salmon entering Smith Inlet in 2006 and 2007. The changing correlations may provide the first indication that sockeye marine survival is shifting back to levels that were more typical of Smith Inlet sockeye salmon prior to the virtual collapse of this stock in the early 1990s (Fig. 11).
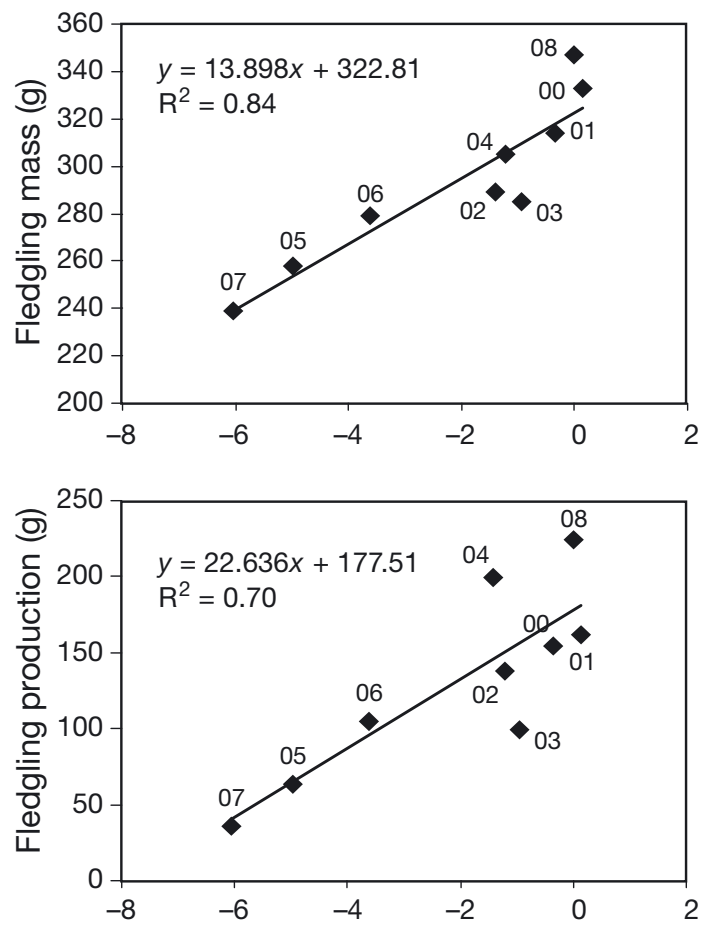

Average alongshore wind velocity April 8 to $22\left(\mathrm{~m} \mathrm{~s}^{-1}\right)$

Fig. 10. Cerorhinca monocerata. Several metrics of rhinoceros auklet breeding success are very closely related to average alongshore wind velocity during mid-April (winds from the north are positive). Numbers next to data points are years (yy) 
Table 4. Cerorhinca monocerata and Oncorhynchus nerka. Correlation and level of significance for the comparison between rhinoceros auklet fledgling mass and $\log _{10}$ Smith Inlet sockeye salmon marine survival $\left(\log _{10}\right.$ survival) for 2 time periods

\begin{tabular}{|lcccccc|}
\hline & \multicolumn{3}{c}{$1995-2004$} & \multicolumn{3}{c|}{$1995-2007$} \\
& $\mathrm{n}$ & $\mathrm{R}^{2}$ & $\mathrm{p}$ & $\mathrm{n}$ & $\mathrm{R}^{2}$ & $\mathrm{p}$ \\
\hline Fledging success & 10 & 0.43 & 0.02 & 13 & 0.02 & 0.62 \\
Fledgling mass & 10 & 0.69 & $<<0.01$ & 13 & 0.30 & 0.03 \\
Fledgling production & 10 & 0.47 & 0.01 & 13 & 0.12 & 0.21 \\
$\log _{10}$ survival & 6 & 0.81 & $<0.01$ & 9 & 0.07 & 0.84 \\
\hline
\end{tabular}

\section{DISCUSSION}

Our observations suggest a seasonally varying winddriven production system in southern Queen Charlotte Sound, in which both spring and summer conditions are important. We suggest that estuarine-type circulation of nutrient-rich water offshore of the mouth of Rivers and Smith inlets, especially during spring, results in a plume of chlorophyll-rich water carried westward across the north end of Vancouver Island towards Triangle Island (Fig. 12). The timing of the relaxation of winter winds from the southeast, and the transition to northwest winds, appear to be of critical importance in determining the early survival and subsequent recruitment of young-of-the-year (YOY) Pacific sandlance on which rhinoceros auklets breeding on Triangle Island feed. Our observations suggest that when this productive water arrives over Cook Bank and Triangle Island early in the spring, and is maintained throughout the summer by northwest winds, it provides good feeding opportunities for juvenile sandlance and, through them, the rhinoceros auklets. A more detailed discussion of the individual linkages follows.

\section{Spring chlorophyll}

Ware \& Thomson (2005) found a linear relationship over many years between annual production of resident fish and average annual chlorophyll on the west

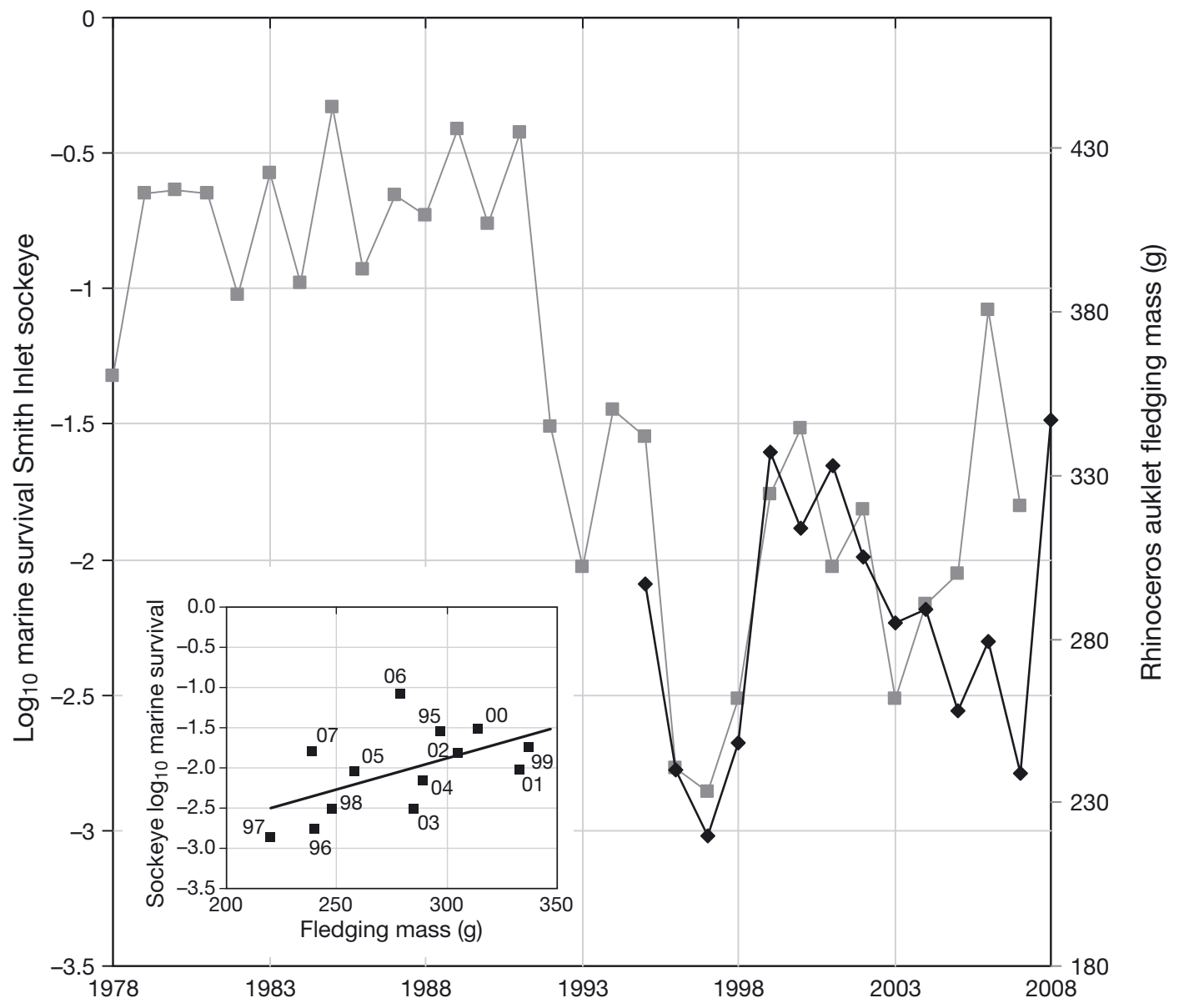

Fig. 11. Cerorhinca monocerata and Oncorhynchus nerka. Following the collapse of the Smith Inlet sockeye salmon in the early 1990s, there was a close relationship (inset) between the logarithms of sockeye marine survival ( $\square$ ) and fledgling mass of rhinoceros auklets at Triangle Island $(\bullet)$. Numbers next to data points are years (yy) 


\section{SE winds prevalent in winter must abate or become NW winds in early April in order to allow the westward surface flow to begin. These conditions must continue throughout the summer}

3. Seabirds at Triangle Island are dependent on recruitment of sandlance, which is linked to the arrival of high chlorophyll waters in April.

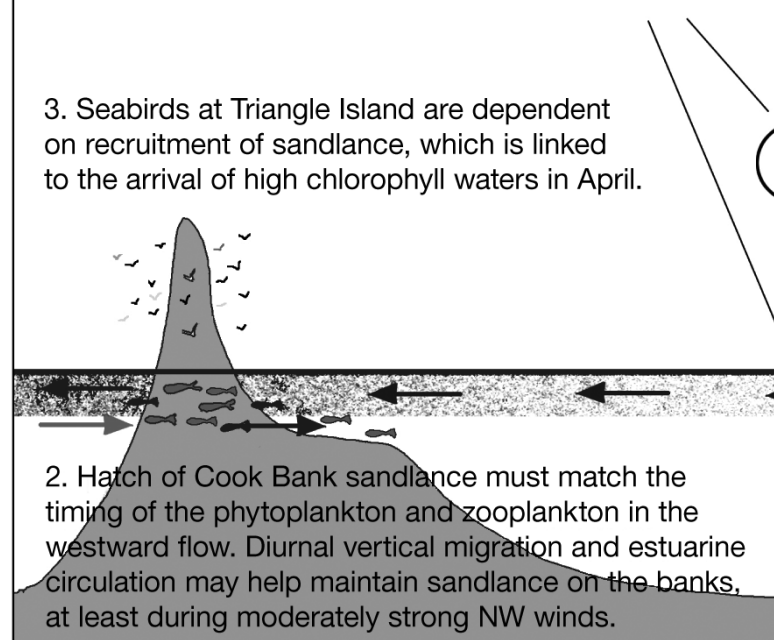

Fig. 12. Cerorhinca monocerata. Breeding success of rhinoceros auklets at Triangle Island appears to be linked to the survival and maintenance of Pacific sandlance Ammodytes hexapterus on Cook Bank, which depends on the arrival of productive water masses from the east marked by elevated chlorophyll in the first $2 \mathrm{wk}$ of April, and continuation of this regime over the summer. This westward surface flow depends on a reduction of southeast winds during the spring and summer, and their replacement by winds from the north $(\odot$ : wind blowing out of the plane of the figure toward the viewer)

coast of North America. In the present study, we demonstrate a relationship between chlorophyll and seabird production at much shorter temporal and spatial scales-but only during the spring (Table 1). Chlorophyll phenology around the seabird colony at Triangle Island and across southeastern Queen Charlotte Sound was clearly related to the timing of the relaxation of winter, downwelling-favorable winds from the southeast in spring.

We find that the breeding success of rhinoceros auklets correlated extremely closely with the timing of the arrival of chlorophyll-rich waters around the colony, peaking in early April near the time of the arrival of the adults from the south and a few weeks before egg laying begins (Fig. 5). This supports our first hypothesis that interannual variation in local marine primary productivity is a critical factor driving interannual variation in the breeding success of this seabird. At the population level, the rhinoceros auklets at Triangle Island breed more successfully in years in which they lay early (Hipfner et al. 2008), and early laying may be facilitated by an early spring bloom that creates good feeding conditions during the critical period when females are accumulating reserves and beginning to produce eggs. At this time of year, rhinoceros auklets feed on a mixed diet including both fish and lower trophic level prey such as euphausiids (Davies et al. 2009, Ito et al. 2009). In years in which chlorophyll concentrations in local waters are high, their eggs tend to be especially rich in carotenoids, which are lipidsoluble pigments synthesized exclusively by primary producers (Hipfner et al. 2010a). In addition, the presence of the carotenoids lutein and zeaxanthin in egg yolks suggested that rhinoceros auklets might feed on juvenile sandlance at this time, since both of these carotenoids were found in juvenile sandlance but not in other potential prey items (Hipfner et al. 2010b).

\section{Sandlance}

We found strong links between springtime (April) chlorophyll concentration and the amount of YOY sandlance fed to nestling rhinoceros auklets several months later (July, August), and then between the amount of sandlance in diets and measures of the birds' breeding success. These results support our second hypothesis, which stated that the relationship between strong breeding success and increased chlorophyll concentrations would be due at least in part to an effect of increased chlorophyll on increased recruitment of sandlance, and thus on the availability of sandlance to the auklets (Bertram et al. 1991, Hedd et al. 2006). There is very little quantitative data on sandlance biology in British Columbia waters, but central to our interpretation of these results is the notion that the 
amount of sandlance in nestling diets reflects their abundance and/or their accessibility to the birds (see also Bertram \& Kaiser 1993).

There were close relationships among the date of the relaxation of winter winds in Queen Charlotte Sound, the timing of the local phytoplankton bloom, the amount of sandlance in the diet of the chicks, and fledgling production. While phytoplankton blooms in the area occurred between late March (in the 1998 El Niño year) and mid-May (2007), the birds were most successful when phytoplankton-rich waters arrived around the islands during the first 2 wk of April and were sustained through early May by long or at least repeated periods of northwest winds. Blooms were first generated along the mainland coast in the vicinity of Rivers and Smith inlets following relaxation of southerly winds after 30 March. Winds from the north prior to 30 March did not generate blooms, perhaps due to low light levels or absence of shallow surface layers to keep plankton suspended within the euphotic zone.

The surface currents flowing west across Cook Bank and through the Scott Group of Islands bring this phytoplankton-rich water to Triangle Island. Fledging success, fledgling mass, and overall fledgling production were all highest when the spring chlorophyll bloom came early in April and southeast winter winds decreased, allowing the flow of coastal water from the vicinity of Smith and Rivers inlets for prolonged periods. Close comparison of sequences of daily chlorophyll images with wind data show that the westward flow past Triangle Island under northwest winds is pushed north away from the colony if winds change direction to blow from the south or southwest.

We found that the amount of juvenile sandlance in the chicks' diet over the summer is greatest in years of strong and early primary production, as suggested by Bertram \& Kaiser (1993). The later the spring bloom, the less sandlance fed to the chicks (Fig. 7), suggesting that recruitment of sandlance that hatch during March depends on the timing of the spring bloom.

Robards et al. (2002) concluded that at least on a decadal scale, Gulf of Alaska sandlance and other forage fish were more profoundly affected by changes in abundance and quality of their planktonic food than by temperature alone. We interpret our findings to suggest very tight linkages among the auklets (secondary consumers), juvenile sandlance (primary and secondary consumers) that feed heavily on copepods and small zooplankton (primary consumers), and the phytoplankton on which the small zooplankton and larval sandlance feed in the spring (Robinson et al. 1968, Scott 1973). Strong correlations between spring chlorophyll and the percentage of sandlance biomass fed to the chicks later in the summer suggest that early phytoplankton availability (and presumably the cope- pods and other zooplankton that juveniles feed on) controls early survival and year-class strength of sandlance. The fact that the percentage of adult sandlance in the chicks' diet is not related to April chlorophyll in the same year, but is linked to spring chlorophyll of the previous year, reinforces this conclusion.

Sandlance spawning in Puget Sound, Washington, USA, and the Strait of Juan de Fuca occurs in February and March (Penttila 2007). Eggs hatch in March and April in synchrony with the spring plankton bloom. On the outer coast of Vancouver Island, the median size of YOY sandlance in Barkley Sound (Fig. 1) in mid-May was 40 to $50 \mathrm{~mm}$, with growth rates of $0.4 \mathrm{~mm} \mathrm{~d}^{-1}$ (C. Robinson pers. comm.). From these dates of sampling, sizes and growth rates, we can calculate that the Barkley Sound sandlance hatched sometime between 23 March and 17 April, thus confirming that they (and presumably those over Cook Bank also) were indeed planktonic during the last week of March and the first 2 wk of April. During their planktonic phase, juvenile sandlance feed on phytoplankton and invertebrate eggs, but feed on copepod nauplii and adult copepods as they increase in size. If the spring bloom is late, then the sandlance can be expected to fail (Fig. 7), leading to a knock-on effect on the auklets (Fig. 5).

It is also possible that northwest winds help to retain vertically migrating zooplankton and sandlance around the colony. Rhinoceros auklets implanted with subcutaneous radio tags in 2002 (a 'good' year) foraged on Cook Bank during a period in mid- to late July when sandlance dominated nestling diets (McFarlaneTranquilla et al. 2005). During periods of winds from the northwest, Crawford et al. (1985) found eastward near-surface and deep currents in Goose Island Gully just north of Cook Bank compensating for the westward surface flow. (Deep currents were not measured on Cook Bank, but it is likely they too flow eastward.) Together with sandlance diurnal vertical migration, we can speculate that this counter-current will serve to retain sandlance on Cook Bank. In years with more sustained northwest winds throughout the summer, it is reasonable to expect a higher availability of sandlance, as suggested by the high correlations with SST later in the summer in our data.

\section{Coastal SST}

Bertram et al. (2001) showed that growth rates and survival of rhinoceros auklet nestlings at Triangle Island during the period 1976 to 2001 were negatively correlated with SST measured in April at the Pine Island light station, $\sim 100 \mathrm{~km}$ east of the Scott Island group. Hedd et al. (2006) demonstrated that the relationship with Pine Island SST was clearly related to 
diet composition. However, their data showed that the relationship did not hold in 1976, and it broke down again in 2007 (Hipfner 2008b). In both of these years the birds bred unsuccessfully despite cold ocean temperatures in April. Our examination of satellitederived SST near the colony shows similar negative correlations between measures of breeding success and Pine Island SST in April, but even stronger correlations later in the summer, in agreement with data presented by Thayer et al. (2008). Our data also show that the linkages were much stronger and more persistent with SST at Egg Island. These observations lead us to conclude that during summer, upwelling resulting from northwest winds in that region, and westward advection of the resulting highly productive waters to Triangle Island, are important determinants of the seabird productivity there. In this scenario, cool SSTs signal westward advection of upwelled and tidally mixed water during summer.

The reason for the finding that the year 2007 was an outlier on the Pine Island April SST versus production plot appears to be that timing of the transition from winter to spring conditions (and the resulting spring plankton bloom) is more important than absolute temperature. Monthly SST averages for April usually relate to breeding success as long as the shift in winds and consequent phytoplankton bloom also occur sometime within that month. The winter of 2006-07 was abnormally harsh, and SSTs were well below normal across the entire Gulf of Alaska (Crawford 2008). The storms continued into early 2007, and March was dominated by three Pacific storm systems that deposited record amounts of rain and snow (150 to $200 \%$ of normal) over large areas of the mountains of the central coast (British Columbia Ministry of Environment 2007). The April water temperatures were low, but the temperature relationship failed because April winds were still from the south and the wind shift and phytoplankton bloom did not occur until mid-May in that year (Fig. 4). While we did not examine data from outside the 1998 to 2008 period here, we can show that in 1976 , the other year in which the SST/production relationship failed (Hedd et al. 2006), the average April winds were also from the south, as determined by monthly distribution of air pressure. Our analysis makes it seem likely that that depressed SST in Queen Charlotte Sound in April 1976 was not related to winds from the northwest.

\section{Coastal salinity}

The summer salinity at Egg Island was abnormally low in both 2007 and 1976. The years were similar, with similar southerly winds throughout the winter and spring that brought heavy precipitation (British Columbia Ministry of Environment 2007) and runoff that grossly depressed surface salinities at the time of peak Wannock River discharge into Rivers Inlet and the outer waters of Smith Inlet later in June. We have shown that rhinoceros auklet fledging success was inversely proportional to Egg Island salinity in most months, and especially so in June-perhaps suggesting that upwelling of more saline water leads to more productivity at all trophic levels. This is similar to the finding that marine survival of juvenile sockeye salmon in Rivers Inlet is low when the Wannock River discharge is high (Routledge 2006). The June linkage with runoff and salinity is probably a delayed signal of the heavy precipitation during the preceding harsh winter and spring. We interpret this linkage not as a direct effect of salinity on the auklets (or on juvenile sockeye salmon), but as another indirect correlate with timing; in years with harsh winters and low coastal salinity, the spring bloom was late, which adversely affected recruitment of the sandlance. Tomassi (2008) showed that higher freshwater discharge lowered nutrient concentrations in the euphotic zone of Rivers Inlet rather than increased them.

\section{Wind-driven advection}

Although we can associate good fledgling production with upwelling of nutrients by northwest winds along the mainland coast in summer, and subsequent wind-driven advection of nutrient-rich water to Triangle Island, this is not likely the critical oceanic process in April. The coastal ocean is not nutrient-limited in April. Instead we usually see a spring plankton bloom in this month that begins to consume nutrients mixed into surface waters over the winter. Additionally, even in good production years the upwelling winds are rather weak. We suspect that several other factors are important at this time of the year.

Flow of zooplankton-rich waters past Triangle Island from Queen Charlotte Sound seems to be the most likely explanation for the (assumed) local abundance of sandlance and the productivity of the rhinoceros auklet colony there. High chlorophyll concentrations in Canadian waters north of Vancouver Island in spring are first observed in southeast Queen Charlotte Sound, and we expect that these blooms support the earliest zooplankton populations. When winter winds from the southeast relax in the spring (such as when southeast wind component reaches zero in Fig. 9), these plankton-rich waters in southeast Queen Charlotte Sound flow westward past and through the Scott Islands. Such flows are observed regularly in summer with winds 
from the northwest (Crawford et al. 1985, 1999) and in QuickSCAT imagery (available at www.remss.com, not shown here) for individual days during the spring and summer. Even the monthly average chlorophyll images in Fig. 3 show evidence of this flow in 3 productive years, 1999, 2000, and 2004.

We think this is due to estuarine-type outflow in southern Queen Charlotte Sound rather than a windforced barotropic current. During calm-to-moderate northwest winds, this outflow will be driven seaward across the sound by the hydraulic head formed by brackish outflow from the mainland inlets. Because this hydraulic head is associated with a distributed source (not a point source) extending from the vicinity of Egg Island to Hecate Strait, it will have a lateral integrity that exceeds the distance to Triangle Island and, therefore, will not easily turn north under the influence of winds and Coriolis effects.

The match or mismatch of the timing of the relaxation of winter winds, phytoplankton bloom, and the inferred growth and survival of juvenile sandlance is similar to that proposed by Cushing (1975) and many others since. Cushing found that North Sea herring that spawn at a fixed time of the year are critically dependent on synchrony of plankton production. Mismatched timing leads to poor year-class strength. Similarly, Bertram et al. (2001) found linkage between April SST and nestling growth rates for both Cassin's auklets Ptychoramphus aleuticus and rhinoceros auklets at Triangle Island, and argued for a seasonal mismatch when spring was early and warm. Wolf et al. (2009) has recently shown that the timing of egg laying of Cassin's auklets is correlated with satellite-derived chlorophyll concentration and sea surface height at Triangle Island in April. (Sea surface height is largely controlled by alongshore winds. We also examined correlations with sea surface height, but found much stronger correlations with the average alongshore wind speed.) We did not measure within-season variation in rhinoceros auklets diets and its relationship to chlorophyll, so we cannot directly address the matchmismatch question with this species. However, we found that early survival of the sandlance (that feed heavily on copepod nauplii and other herbivorous zooplankton, and the phytoplankton that the small zooplankton feed on) appears to be controlled by the timing of the transition from southerly to northerly winds in April that regulate currents in the area. The timing of this transition is almost certainly related to larger atmospheric processes over the northeast Pacific. Although different in detail, our observations are very similar to those of Takahashi et al (2001) and Watanuki et al. (2009), who have shown that breeding success of rhinoceros auklets at Teuri Island in the northern Japan Sea is controlled by availability of energy-rich prey, brought to the colony by oceanic currents that vary with large scale atmospheric pressure differences over the North Pacific.

\section{Relevance to sockeye salmon}

Recently, Roth et al. (2007) and Sydeman et al. (2008) have suggested that since both seabirds and salmon often respond to bottom-up effects, the co-variance of both groups is useful in salmon forecasting. We are able to show that from 1995 to 2003, the marine survival of Smith Inlet sockeye was moderately to highly correlated with the fledgling mass of rhinoceros auklets in the year the sockeye cohort went to sea (Table 4 and Fig. 11) and with the amount of sandlance fed to the auklets' chicks, suggesting that the physical factors controlling the early survival and recruitment of the sandlance impact both auklet chicks and juvenile sockeye. In the case of the auklets, the ultimate factor seems to be the wind regime, and therefore this might also be the case for the salmon, too.

We are certainly not the first to suggest linkages between the wind regime and survival of marine species on the British Columbia coast. Wickett \& Ballantyne (1980) showed that $78 \%$ of the interannual variation of Rivers Inlet sockeye salmon catch from 1948 to 1972 was accounted for by a combination of salmon spawner abundance and sea-level variation (which is related to the prevailing alongshore wind direction). McKinnell et al. (2001) reported a strong linkage between winds from the northwest in April and the fryto-adult survival index for Rivers Inlet sockeye, and speculated that the timing of the transition from downwelling to upwelling winds in spring could affect survival by determining the productivity regime into which the juvenile fish entered. Although this is entirely consistent with our findings, it is certainly not the entire story, given that Smith Inlet sockeye exhibit a much broader range of marine survival over the full period of record than during the shorter interval in which both salmon and auklet metrics are available for comparison (Fig. 11).

Between the 1993 and 2005 sea-entry years, Smith Inlet sockeye salmon exhibited an average annual marine survival of only $1.3 \%$ (range: 0.1 to $3.5 \%$ ). By contrast, between sea-entry years 1978 and 1992, their average marine survival was more than an order of magnitude higher (mean: $21 \%$, range: 3.1 to $46.9 \%$ ). One consequence of these observations is that the remarkably tight coupling between auklet metrics and sockeye salmon marine survival observed between 1993 and 2005 could not have existed in the same form over the entire interval of 1978 to 2005, during which sockeye survival varied across such a large 
range. The very sudden transition in 1991 and 1992 from relatively high to consistently much lower marine survival might suggest a major ocean production regime-shift (Polovina 2005) of as yet unknown origins. Alternatively and perhaps more likely, a change in timing of winds, currents, and/or bloom timing at that time could have created a significant mismatch with smolt sea entry after 1991 that gradually has lessened in the 2 decades since then. The increases in marine survival observed for sea-entry years 2006 and 2007 may suggest a return to favorable survival conditions for Smith Inlet sockeye. These possibilities should be explored further. The changing correlations and conceptual model presented here provide a new avenue of research.

\section{CONCLUSIONS}

Our data show that the breeding success of rhinoceros auklets at Triangle Island is tied to the timing of winds, water movements, phytoplankton blooms (and by inference zooplankton), and availability of juvenile sandlance. We can infer from these observations that these birds will be vulnerable to climate change and disruptions of normal weather patterns, in a fashion similar to that proposed by Beamish \& Bouillon (1993), who showed linkages between the position of the Aleutian low pressure zone in the North Pacific (and hence the coastal wind regime) and Pacific salmon production. Long-term or sudden changes in the timing or magnitude of these events could have major impact on the rhinoceros auklet population. Our observations support suggestions by others (Wickett \& Ballantyne 1980, McKinnell et al. 2001) that changes in the wind regime will also impact the marine survival of local sockeye salmon. Finally, this work has broader implications. This study of relationships between seabird breeding success with wind and chlorophyll (both derived from global satellite data that are freely available) provide potentially valuable exploratory tools that will be widely applicable to studies of early marine survival of juveniles of many marine species.

Acknowledgements. We thank L. Brown, P. Willis, M. Martinez, and R. Kerr of ASL Environmental Sciences Inc. for excellent technical assistance. I. Pearsall, C. Robinson (Parks Canada), and V. Barrie (Natural Resources Canada) provided important information regarding sandlance and Cook Bank. Three anonymous reviewers provided very helpful suggestions to improve the manuscript. Careful editing by several amazing MEPS editors is also gratefully acknowledged. This work was funded by the Canadian Space Agency through the Government Related Initiatives Program (GRIP) of the Canadian Space Agency, to W.C. and R.T. of Fisheries and Oceans Canada, as well as by Borstad Associates Ltd and ASL Environmental Sciences Inc. Field work on Triangle Island from
1998 to 2008 was funded primarily by the Center for Wildlife Ecology at Simon Fraser University and by Environment Canada. This study was only possible because of the calibrated, mapped and composited global satellite data freely provided by the US National Aeronautics and Space Administration (NASA).

\section{LITERATURE CITED}

Abraham CL, Sydeman WJ (2004) Ocean climate, euphausiids and auklet nesting: inter-annual trends and variation in phenology, diet and growth of a planktivorous seabird Ptychoramphus aleuticus. Mar Ecol Prog Ser 274:235-250

Aebischer NJ, Coulson JC, Colebrook JM (1990) Parallel longterm trends across four marine trophic levels and weather. Nature 347:753-755

Ainley DG, Boekelheide RJ 1990. Seabirds of the Farallon Islands: ecology, dynamics, and structure of an upwellingsystem community. Stanford University Press, Palo Alto, CA

- Beamish RJ, Bouillon DR (1993) Pacific salmon production trends in relation to climate. Can J Fish Aquat Sci 50: 1002-1016

Bertram DF, Kaiser GW (1993) Rhinoceros auklet (Cerorhinca monocerata) nestling diet may gauge pacific sand lance (Ammodytes hexapterus) recruitment. Can J Fish Aquat Sci 50:1908-1915

Bertram DF, Kaiser GW, Ydenberg RC (1991) Patterns in the provisioning and growth of nestling rhinoceros auklets. Auk 108:842-852

Bertram DF, Mackas DL, McKinnell S (2001) The seasonal cycle revisited: interannual variation and ecosystem consequences. Prog Oceanogr 49:283-307

British Columbia Ministry of Environment (2007) Snow pack and water supply outlook for British Columbia. Water Stewardship Division website. Available at http://bcrfc. env.gov.bc.ca/bulletins/watersupply/archive.htm (accessed February 2011)

> Burger AE, Wilson RP, Garnier D, Wilson MPT (1993) Diving depths, diet, and underwater foraging of rhinoceros auklets in British Columbia. Can J Zool 71:2528-2540

Cairns DK (1987) Seabirds as indicators of marine food supplies. Biol Oceanogr 5:261-271

Crawford WR (2008) Northeast Pacific and Gulf of Alaska, cooling ocean from summer 2007 to winter 2008. In: Irvine J, Crawford WR (eds) State of physical, biological, and selected fishery resources of Pacific Canadian marine ecosystems. Canadian Science Advisory Secretariat Research Document 2008/013. Fisheries and Oceans Canada, Nanaimo, p 25-27. Available at www.dfo-mpo. gc.ca/CSAS/Csas/Publications/ResDocs-DocRech/2008/ 2008_013_e.pdf

Crawford WR, Huggett WS, Woodward MJ, Daniel PE (1985) Summer circulation of the waters of Queen Charlotte Sound. Atmos-Ocean 23:393-413

Crawford WR, Cherniawsky JY, Cummins P (1999) Surface currents in British Columbia coastal waters: comparison of observations and model predictions. Atmos-Ocean 37: $255-280$

Crawford WR, Johannessen D, Whitney F, Birch R, Borg K, Fissell D, Vagle S (2006) Appendix C: physical and chemical oceanography. In: Lucas BG, Verrin S, Brown R (2007) Ecosystem overview: Pacific North Coast Integrated Management Area (PNCIMA). Can Tech Rep Fish Aquat Sci 2667

> Croll DA, Marinovic B, Benson S, Chavez FP, Black N, Ternullo $\mathrm{R}$, Tershy BR (2005) From wind to whales: trophic links 
in a coastal upwelling system. Mar Ecol Prog Ser 289: $117-130$

Cushing DH (1975) Marine ecology and fisheries. Cambridge University Press, London

> Davies WE, Hipfner JM, Hobson KA, Ydenberg RC (2009) Seabird seasonal trophodynamics: isotopic patterns in a community of Pacific alcids. Mar Ecol Prog Ser 382: 211-219

Davoren GK, Montevecchi WM (2003) Signals from seabirds indicate changing biology of capelin stocks. Mar Ecol Prog Ser 258:253-261

Edwards M, Richardson AJ (2004) Impact of climate change on marine pelagic phenology and trophic mismatch. Nature 430:881-884

Fabry VJ (2008) Marine calcifiers in a high- $\mathrm{CO}_{2}$ ocean. Science 320:1020-1022

Freeland HJ, Crawford WR, Thomson RE (1984) Currents along the Pacific coast of Canada. Atmos-Ocean 22: 151-172

> Gjerdrum C, Vallee AM, St. Clair CC, Ryder JL, Bertram DF, Blackburn GS (2003) Tufted puffin reproduction reveals ocean climate variability. Proc Natl Acad Sci USA 100: 9377-9382

Hedd A, Bertram DF, Ryder JL, Jones IL (2006) Effects of inter-decadal climate variability on marine trophic interactions: rhinoceros auklets and their fish prey. Mar Ecol Prog Ser 309:263-278

Hipfner JM (2008a) Matches and mismatches: ocean climate, prey phenology and breeding success in a zooplanktivorous seabird. Mar Ecol Prog Ser 368:295-304

Hipfner JM (2008b) Seabird reproductive performance on Triangle Island in 2007: a late and unsuccessful breeding season. In: Irvine J, Crawford WR (eds) State of physical, biological, and selected fishery resources of Pacific Canadian marine ecosystems. Canadian Science Advisory Secretariat Research Document 2008/013. Fisheries and Oceans Canada, Nanaimo, p 62-63. Available at www. dfo-mpo.gc.ca/CSAS/Csas/Publications/ResDocs-DocRech/ 2008/2008_013_e.pdf

Hipfner JM, McFarlane-Tranquilla LA, Addison B (2008) Do marine birds use environmental cues to optimize egg production? An experimental test based on relaying propensity. J Avian Biol 39:611-618

Hipfner JM, Dale J, McGraw KJ (2010a) Yolk carotenoids and stable isotopes reveal links among foraging behavior, environment, and seabird breeding success. Oecologia 163:351-360

Hipfner JM, Hobson KA, Dale J, McGraw KJ (2010b) Stable isotopes link diet to avian yolk carotenoid allocation: a comparative study of five auk species (Charadriiformes: Alcidae). Physiol Biochem Zool 83:481-489

Hyatt KD, Rutherford DG, Gjernes T, Rankin DP, Cone T (1984). Lake enrichment program: juvenile sockeye unit survey guidelines. Can M Rep Fish Aquat Sci 1796

Hyatt K, Hunter K, Stockwell M, Rankin P (2008). Sockeye salmon index stocks - regional overview of trends and 2007 returns. In: Irvine J, Crawford WR (2008) State of physical, biological, and selected fishery resources of Pacific Canadian marine ecosystems. Canadian Science Advisory Secretariat Research Document 2008/013. Fisheries and Oceans Canada, Nanaimo, p 73-77. Available at www.dfo-mpo.gc.ca/CSAS/Csas/Publications/ResDocsDocRech/2008/2008_013_e.pdf

> Ito M, Minami H, Tanaka Y, Watanuki Y (2009) Seasonal and inter-annual oceanographic changes induce diet switching in a piscivorous seabird. Mar Ecol Prog Ser 393: 273-284
Kato A, Watanuki Y, Naito Y (2003) Foraging behaviour of chick-rearing rhinoceros auklets Cerorhinca monocerata at Teuri Island, Japan, determined by acceleration-depth recording micro data loggers. J Avian Biol 34:282-287

- Mackas DL, Batten S, Trudel M (2007) Effects on zooplankton of a warmer ocean: recent evidence from the northeast Pacific. Prog Oceanogr 75:223-252

McFarlane-Tranquilla L, Ryder JL, Boyd WS, Shisko SG, Amey K, Bertram DF, Hipfner JM (2005) Diurnal marine distributions of radio-tagged Cassin's auklets and rhinoceros auklets breeding at Triangle Island, B.C. Canadian Wildlife Service Tech Rep Ser 423

McGowan JA, Cayan DR, Dorman LM (1998) Climate-ocean variability and ecosystem response in the northeast Pacific. Science 281:210-217

> McKinnell SM, Wood CC, Ruthorford DT, Hyatt KD, Welch DW (2001) The demise of Owikeno Lake sockeye salmon. North Am J Fish Manag 21:774-791

Miller AK, Sydeman WJ (2004) Rockfish response to low-frequency ocean climate change as revealed by the diet of a marine bird over multiple time scales. Mar Ecol Prog Ser 281:207-216

Myers RA, Worm B (2005) Extinction, survival, or recovery of large predatory fishes. Philos Trans R Soc Lond Ser B 360:13-20

Penttila D (2007) Marine forage fishes in Puget Sound. Puget Sound nearshore partnership report No. 2007-03. Seattle District, U.S. Army Corps of Engineers, Seattle, WA

Polovina JJ (2005) Climate variation, regime shifts, and implications for sustainable fisheries. Bull Mar Sci 76:233-244

Reed TE, Wanless S, Harris MP, Frederiksen M, Kruuk LEB, Cunningham EJA (2006) Responding to environmental change: plastic responses vary little in a synchronous breeder. Proc R Soc Lond B 273:2713-2719

Richardson AJ (2008) In hot water: zooplankton and climate change. ICES J Mar Sci 65:279-295

Robards MD, Rose GA, Piatt JF (2002) Growth and abundance of Pacific sand lance, Ammodytes hexapterus, under differing oceanographic regimes. Environ Biol Fishes 64:429-441

Robinson DG, Barraclough WE, Fulton JD (1968) Number, size composition, weight and food of larval and juvenile fish caught with a two-boat surface trawl in the Strait of Georgia June 5-9, 1967. Fish Res Board Can Manuscr Rep 972

Roth JE, Mills KL, Sydeman WJ (2007) Chinook salmon (Oncorhynchus tshawytscha) - seabird covariation off central California and possible forecasting applications. Can J Fish Aquat Sci 64:1080-1090

Routledge R (2006) Testimony at the special committee on sustainable aquaculture second session, 38th parliament of the 2006 British Columbia legislative session. Available at www.leg.bc.ca/cmt/38thparl/session-2/aquaculture/ hansard/W61205a.htm (accessed 22 February 2011)

Scott JS (1973) Food and inferred feeding behaviour of northern sandlance (Ammodytes dubius). J Fish Res Board Can 30:451-454

Scott BE, Sharples J, Ross ON, Wang J, Pierce GJ, Camphuysen CJ (2010) Sub-surface hotspots in shallow seas: finescale limited locations of top predator foraging habitat indicated by tidal mixing and sub-surface chlorophyll. Mar Ecol Prog Ser 408:207-226

> Sydeman WJ, Bradley RW, Warzybok P, Abraham CL and others (2006) Planktivorous auklet Ptychoramphus aleuticus responses to ocean climate, 2005: unusual atmospheric blocking? Geophys Res Lett 33:L22S09 doi: 10.1029/2006 GL026736 
Sydeman WJ, Abraham CL, Byrd GV (2008) Seabird-sockeye salmon co-variation in the eastern Bering Sea: phenology as an ecosystem indicator salmonid predictor? Deep-Sea Res II 55:1877-1882

Takahashi A, Kuroki M, Niizuma Y, Kato A, Saito A, Watanuki Y (2001) Importance of the Japanese anchovy Engraulis japonicus to breeding rhinoceros auklets Cerorhinca monocerata on Teuri Island, Sea of Japan. Mar Biol 139:361-371

Thayer JA, Bertram DF, Hatch SA, Hipfner JM, Slater L, Sydeman WJ, Watanuki Y (2008) Forage fish of the Pacific Rim as revealed by diet of a piscivorous seabird: synchrony and relationships with sea surface temperature. Can J Fish Aquat Sci 65:1610-1622

Tomassi D (2008) Seasonal and interannual variability of primary and secondary productivity in a coastal fjord. MSc thesis, Simon Fraser University, Vancouver

$>$ Ware DM, Thomson RE (2005) Bottom-up ecosystem trophic dynamics determine fish production in the northeast

Editorial responsibility: Hans Heinrich Janssen, Oldendorf/Luhe, Germany
Pacific. Science 308:1280-1284

- Watanuki Y, Ito M, Deguchi T, Minobe S (2009) Climateforced seasonal mismatch between the hatching of rhinoceros auklets and the availability of anchovy. Mar Ecol Prog Ser 393:259-271

Wells BK, Field JC, Thayer JA, Grimes CB and others (2008) Untangling the relationships among climate, prey and top predators in an ocean ecosystem. Mar Ecol Prog Ser 364: $15-29$

Whitehead H, O'Brien K, Worm B (2010) Diversity of deepwater cetaceans and primary production. Mar Ecol Prog Ser 408:1-5

Wickett WP, Ballantyne A (1980) Yield charts for north coast B.C. salmon populations based on freshwater and ocean survival indices. Can Tech Rep Fish Aquat Sci 978

Wolf SG, Sydeman WJ, Hipfner JM, Abraham CL, Tershy BR, Croll DA (2009) Wide range reproductive consequences of ocean climate variability for the seabird Cassin's auklet. Ecology 90:742-753

Submitted: July 8, 2010; Accepted: November 22, 2010

Proofs received from author(s): February 23, 2011 